\title{
ONLINE INSURANCE EXISTENCE IN INDONESIA BASED ON ISLAMIC LEGAL PERSPECTIVE AS A PROTECTION OF SPIRITUAL RIGHTS
}

\author{
Hari Sutra Disemadi, Paramita Prananingtyas \\ Faculty of Law, Diponegoro University \\ Email: haridisemadi@gmail.com
}

\section{Abstract}

Globalization era requires Indonesia to always use technology and information in improving economy. This also applies to insurance companies that have implemented technology and information. Conventional insurance has developed into online one that attracts Indonesian citizen. However, today new issue is about protecting the spiritual rights of consumers as well as the halal or haram of online insurance. Answering this problem, this research will use normative juridical (doctrinal) method that prioritizes primary legal material i.e. insurance laws, consumer protection laws, and other legal materials. This research shows the existence of online insurance in Indonesia which rapidly develops because it offers more conveniences compared to conventional one. In Islamic law, online insurance is allowed as long as it is in line with Islamic law principles in protecting consumers' spiritual rights. The example of sharia principle is cooperation by paying tabarru' funds, using tabarru' and tijarah agreement, and sharing similar responsibility between one participant and others (ta'awun). The legal basis for insurance in Indonesia is contained in the 2014 Law Number 40 and MUI Fatwa Number 21/DSN-MUI/X/2001.

Era globalisasi mengharuskan Indonesia untuk selalu memanfaatkan teknologi dan informasi dalam meningkatkan perekonomian. Ini berlaku pula pada perusahaan asuransiyang telah menerapkan teknologi dan informasi. Asuransi konvensional telah berkembang menjadi asuransi online yang banyak diminati masyarakat Indonesia. Namun, persoalan yang hangat dibicarakan saat ini mengenai perlindungan hak spiritual konsumen serta halal atau haramnya asuransi online. Untuk menjawab persoalan tersebut, penelitian ini menggunakan metode yuridis normatif(doktrinal) 
yang mengedepankan bahan bukum primer yaitu undang-undang perasuransian, undang-undang perlindungan konsumen, serta bahan bukum lain. Penelitian ini menunjukan eksistensi asuransi online di Indonesia telah mengalami perkembangan pesat karena memberikan kemudahan dibanding asuransi konvensional. Dalam bukum Islam, asuransi online pada dasarnya diperbolebkan dengan syarat tidak bertentangan dengan prinsip-prinsip hukum Islam dalam melindungi hak spiritual konsumen. Contohnya prinsip syariah tersebut seperti bekerja sama dengan cara masing-masing mengeluarkan dana tabarru', menggunakan akad tabarru' dan akad tijarah, dan saling menanggung risiko antara satu peserta dengan peserta lainnya (táawun). Dasar hukum mengenai asuransi di Indonesia terdapat dalam UU Nomor 40 Tabun 2014 dan Fatwa MUI Nomor: 21/DSN-MUI/X/2001.

Keywords: Islamic law, online insurance, spiritual rights.

\section{Introduction}

In the current era of globalization, countries in the world are competing to improve their economies. Free trade becomes a dominant issue in the competition for markets. 1 Almost all countries in the world cannot avoid liberalization efforts in the economic field. The real impact of economic liberalization is its impact on society. 2 The community shares all risks and consequences of the rapid economic competition. Social relations, especially modern society as it is today, requires an institution or institution that is willing to take over community risks, both individual and group risks. 3

Until now the public has a relatively higher risk content compared to the past because of technological advances in all fields. 4 Technological advances in such a way affect human life, and can pose broader risks. Thus the institution that has the ability to take over the risk of other parties is the insurance institution. The insurance company has a very broad reach because the insurance company has a range that involves economic interests and social interests. In addition, insurance companies also reach the interests of individuals and the interests of

1 Wiwik Andriani, Pengaruh Kapasitas Sumber Daya Manusia dan Pemanfaatan Teknologi Informasi Terhadap Keterandalan dan Ketepatwaktuan Laporan Keuangan Pemerintah Daerah (Studi pada Pemerintah Daerah Kab. Pesisir Selatan). Jurnal Akuntansi \& Manajemen, Vol.5 No.1, 2010, 69-80, p. 73.

2 Hari Sutra Disemadi \& Kholis Roisah. Kontrak Build Operate Transfer Sebagai Sarana Mewujudkan Kesejahteraan Rakyat. Jurnal Komunikasi Hukum (JKH), Vol.5 No.2, 2019, 126-138, p. 127

3 Hari Sutra Disemadi. Risk Management in the Provision of People's Business Credit As Implementation of Prudential Principles. Diponegoro Law Review, Vol.4 No.2, 194208, 2019, p. 195

4 Lambang Andri Prabawa \& Mohammad Rizan. Perkembangan Teknologi Informasi Dan Komunikasi, Inovasi, Kepemimpinan Dan Kinerja Perusahaan: Studi Transformasi PT. POS Indonesia. Jurnal Pendidikan Ekonomi dan Bisnis, Vol.3 No.1, 2015, 81-99, p. 83 
the wider community. 5

Over the past few years, the development of insurance in Indonesia has shown quite good progress. Insurance companies show a stretch of growth in the business they run, which is increasingly more and more customers are using insurance services in their lives.

Public awareness of the importance of a protection against various types of risks that can occur and befall themselves at any time is one of the causes of the high number of insurance users lately. 6 This of course becomes a distinct advantage for insurance companies that provide insurance services, where a wider market that can be processed and targeted as a product sales they have. But not a few people who do not understand or even do not understand about insurance, types of insurance, insurance goals, and insurance benefits, especially to find out more about insurance.

Indonesia is one of the countries with the most internet users in the world.7 This is a very broad market potential, so online marketing is a must. Now all companies have a website. aiming that the products produced can always be known by the public, so that they can easily enter the market with an online insurance system, the companies will only interact with those who are truly interested in insurance products, selling insurance products will be easier to do. For example, AXA Insurance companies, PT FWD Life Indonesia, Zurich Insurance and Tokopedia Insurance are a small part of insurance companies whose business activities are based on information technology. 8 As digital insurance companies, the above companies base their business activities on information technology.

Based on the current state of the Indonesian economy in the field of online insurance, Muslims are interested in economic institutions that bring them forward in the modern world, provided they are in harmony with the religious spirit and principles of Islamic Law. But a hot issue being discussed in the Islamic world today is halal or the haram of insurance itself. Insurance is haram in all kinds of forms, including online insurance. This opinion was expressed by Sayyid Sabiq,

5 Budi Setyawan. Asuransi Dilihat Dari Perspektif Hukum Islam (Syariah). Retrieved From https:// rangselbudi.wordpress.com/2011/10/26/asuransi-dilihat-dari-perspektif-hukum-islamsyariah/ Accesed $7^{\text {th }}$ August 2019

6 Novi Puspitasari. Sejarah dan Perkembangan Asuransi Islam serta Perbedaannya dengan Asuransi Konvensional. Jurnal Ekonomi Akuntansi dan Manajemen, Vol.10 No.2, 2011, 35-47, p. 39

7 Hari Sutra Disemadi, \& Paramita Prananingtyas. Perlindungan Hukum Terhadap Nasabah Perbankan Pengguna CRM (Cash Recycling Machine). Jurnal Magister Hukum Udayana (Udayana Master Law Journal), Vol.8 No.3, 2019, 286-402, p. 287

8 Duwitmu. 10 Situs Beli Asuransi Online Terbaik Terpercaya 2019 (Diawasi OJK). Retrieved From https:/ / duwitmu.com/asuransi/beli-asuransi-online-terbaik-2019/ Accesed 6 $6^{\text {th }}$ August 2019. 
Abdullah al-Qalqii (mufti of Jordan), Yusuf Qardhawi and Muhammad Bakhil al-Muth i (mufti of Egypt). The reasons they put forward are 1). Insurance is the same as gambling; 2). Insurance contains uncertain elements; 3 ). Insurance contains elements of usury; 4). Insurance contains an element of extortion, because the policyholder if he cannot continue to pay the premium, will lose the premium already paid or reduced; 5). Premiums already paid will be played in usury practices; 6). Insurance including the sale and purchase or exchange of non-cash currencies; and 6). Human life and death are made into business objects and are the same as preceding the destiny of Allah SWT.9

Previous research related to online insurance is by Ramin Cooper Maysami \& John Joseph Williams in 2006, this research focuses on the relationship between Takaful insurance and fundamental perceptions of Islamic principles.10 By Robert E. Keeton in 1970, his research focused on the legal rights of insurance policy holders.11 By Dedi Kusdani in 2014, this study focused on perceptions of attitudes and interests of insurance service consumers who use internet services.12 By Uswatun Hasanah in 2013, his research focused on the Islamic view of insurance, where there are many Indonesian Muslim communities who still do not understand insurance that applies sharia principles.13 By Ahmad Ajib Ridlwan in 2016, his research focused on insurance practices that cannot be separated from the community, gharar and usury.14 Based on previous research, even though the theme is insurance, this research will focus more on the existence of online insurance in Indonesia from the perspective of Islamic law as a protection of spiritual rights. Based on the background above, the focus of the problem in this research is to answer and find out how the existence of online insurance in Indonesia based on the perspective of Islamic law as a protection for the spiritual rights of Muslim consumers.

9 Wong Sadli, Haram Halalkah Asuransi Itu?, Retrieved From https://www.kompasiana.com/sang_wa lisongo/5c7e0aad677ffb416f0d7a48/haram-halalkah-asuransi-itu?page=all Accesed 21th November 2019.

10 Ramin Cooper Maysami \& John Joseph Williams. Evidence on the relationship between Takaful insurance and fundamental perception of Islamic principles. Applied Financial Economics Letters, Vol.2 No.4, 2006, 229-232, p. 229.

11 Robert E. Keeton. Insurance law rights at variance with policy provisions. Harvard Law Review, Vol.83 No.5, 1970, 961-985, p. 961.

12 Dedi Kusdani. Persepsi terhadap sikap dan minat pengguna layanan internet pada perusahaan jasa asuransi. Jurnal organisasi dan manajemen, Vol.10 No.2, 2014, 97-112, p. 97.

13 Uswatun Hasanah. Asuransi dalam Perspektif Hukum Islam. Asy-Syir'ab: Jurnal Ilmu Syaria'ab dan Hukum, Vol.47 No.1, 2013, 239-267, p. 239.

14 Ahmad Ajib Ridlwan. Asuransi Perspektif Hukum Islam. ADZKIYA: Jurnal Hukum dan Ekonomi Syariah, Vol.4 No.1, 2016, 75-88, p.75. 


\section{Research Methods}

The type of legal research used is legal research which is included in the normative legal research typology where this study focuses on positive legal norms in the form of legislation.15 Analytical descriptive is the nature of the research specifications used by the author, because the specifications of this study describe and describe the problem of the object being studied. The data that has been obtained is then collected and then arranged to be analyzed and explained in order to get the conclusions of the research conducted. Secondary data is used in writing this article. Secondary data used comes from primary legal materials such as Law of the Republic of Indonesia Number 40 of 2014 concerning Insurance, Law of the Republic of Indonesia Number 8 of 1999 concerning Consumer Protection, and Fatwa National Sharia Board Number 21 / DSN-MUI / X / 2001 concerning General Sharia Insurance Guidelines. As well as secondary legal materials and tertiary legal materials in the form of books and other legal research journals. The technique used in collecting secondary data is through library research or documentary study, which is a study that examines various documents both related to legislation and other documents that have been available.16 The last thing is compiling data-data that have been obtained so that it becomes a legal writing that is able to answer the problems that have been formulated beforehand so as to help the author make a correct conclusion.

\section{Discussion}

\section{Existence of Online Insurance In Indonesia}

According to the provisions of Article 246 of the Commercial Law (KUHD), insurance or coverage is an agreement whereby the guarantor binds himself to the insured by receiving a premium to provide compensation to him due to loss, damage or loss of expected profits that he may suffer as a result of an event (uncertain event).

Based on these definitions, then the insurance contained 4 elements: 1). The insured party who promised to pay the premium to the insurer, at the same time or gradually; 2). The insurer who promises to pay a sum of money (compensation) to the insured party, at the same time or gradually if something happens that contains an unspecified element; 3 . An accident that is not certain (not known before); and 4). Interests that may experience losses due to events that are not certain.

15 Zainuddin Ali, Metode Penelitian Hukum, (Jakarta: Sinar Grafika, 2018), p. 1.

16 Suteki \& Galang Taufani, Metodologi Penelitian Hukum (Filsafat, Teori Dan Praktik), (Depok: PT RajaGrafindo Persada, 2018), p. 148. 
Law Number 40 of 2014 concerning Insurance covers the following definitions of insurance: Insurance is an agreement between two parties, namely an insurance company and a policy holder, which becomes the basis for receiving premiums by insurance companies in return for: a). Provide compensation to the insured or policy holder due to loss, damage, costs incurred, lost profits, or legal liability to third parties that may suffer the insured or policyholder due to an uncertain event; or b). provide payments based on the death of the insured or payments based on the life of the insured with benefits the amount of which has been determined and / or based on the results of fund management.

Based on the definition above, insurance is a form of agreement which must be fulfilled as stipulated in Article 1320 of the Civil Code, but with the characteristic that insurance is a chance agreement as stated in Article 1774 of the Civil Code. According to Article 1774 of the Civil Code, a chance agreement (kansovereenkomst) is an act whose results, regarding the profit and loss, both for all parties and for some parties, depend on an event that is not necessarily. ${ }^{17}$

The existence of insurance in Indonesia has experienced rapid growth and development. This is evidenced by the existence of digital-based insurers whose business practices rely on information technology and greatly facilitate consumers. ${ }^{18}$

The conveniences offered with online insurance are: First, consumers do not need to meet with insurance company sales. Although the company's sales can help explain the matter of insurance products (which are not easy). Therefore, consumers who are interested in insuring but do not want to deal with insurance agents, can be insured online as a solution; Second, online insurance is not limited by time and place. consumers can do it anytime and anywhere, because all processes are done online so they can save time compared to having to visit an insurance company; Third, online insurance can provide an opportunity for consumers to get cheap premiums, because with online insurance consumers can compare insurance premiums between one product with another product easily, without having to go to the insurance company one by one and consumers can do comparisons and research more freely. Not rushed to have to take a decision immediately, but consumers have the freedom to decide for themselves insurance; Fourth, in online insurance, consumers get access to product reviews because consumers can read reviews of insurance products from people who have previously submitted the

17 Deny Guntara. Asuransi Dan Ketentuan-Ketentuan Hukum Yang Mengaturnya. Jurnal Justisi Imu Hukum. Vol.1 No.1, 2016, 29-44, p. 31.

18 Hal R. Varian. Redistributive taxation as social insurance. Journal of Public Economics. Vol.14 No.1, 1980, 49-68, p. 61-62. 
product. $^{19}$

The existence of online insurance in Indonesia has the same goals as general insurance, namely: a). Risk Transfer. The insured holds insurance online with the aim of transferring the risks that threaten his wealth or life. By paying a premium to the insurance company (guarantor), since then the risk has shifted to the guarantor; b). Compensation Payment. If at any time an event that actually causes a loss (the risk turns into a loss), then the insured will be paid compensation in the amount equal to the amount of insurance. In practice the losses that arise can be partial (partial loss), not all of them in the form of total loss (total loss). Thus, the insured held insurance aims to obtain payment of compensation that is really suffered. ${ }^{20}$

The fundamental difference between online insurance and insurance, in general, is the use of technology, which is that online insurance can be accessed through machines, both computers and mobile phones connected to the internet connection. Online insurance makes it easy for consumers to access insurance compared to having to come directly to the office of the insurance provider.

\section{Online Insurance in Islamic Law Perspectives as a Protection of Spiritual Rights}

Having online insurance can be an effort to financially protect the lives of consumers in the future, because consumers do not know what might happen whether it be property insurance, life insurance, health insurance, or travel insurance. ${ }^{21}$ With online insurance bad things that happen to consumers will get compensation costs by online insurance companies by making a claim. This means that online insurance has protection benefits for anyone registered as an insurance participant, both online insurances managed by the government and private parties. ${ }^{22}$ However, not all Indonesians are aware of the importance of having insurance as a form of personal protection. In fact, most people still consider insurance to have an element that is harmful and contrary to religion.

Regarding online insurance in Indonesia, Islam does not forbid us to have online insurance or insurance in general. Online insurance is permissible as long as the funds collected are managed in accordance with Islamic laws. This was stated in the fatwa of the Indonesian Ulama Council (MUI) Number: 21/DSN-

19 Duwitmu. 10 Situs Beli Asuransi Online Terbaike Terpercaya 2019 (Diawasi OJK). Retrieved From https:// duwitmu.com/asuransi/beli-asuransi-online-terbaik-2019/ Accesed $6^{\text {th }}$ August 2019.

20 Uswatun Hasanah. Asuransi dalam Perspektif Hukum Islam, p.261-261.

21 Hendrisman Rahim. Optimisme Pertumbuhan Asuransi Indonesia; Proyeksi Perkembangan Lima Tahun (2014-2018). Jurnal Asuransi dan Manajemen Risiko, Vol.1 No.2, 2013, 1-21, p.16.

22 Dedi Kusdani. Persepsi Terhadap Sikap dan Minat Pengguna Layanan Internet Pada Perusahaan Jasa Asuransi p.103. 
MUI/X/2001 concerning Sharia Insurance Guidelines. The fatwa contains about how insurance is in accordance with Islamic religious law.

The National Sharia-Indonesian Ulama Council (DSN-MUI) in its fatwa on the General Guidelines for Sharia Insurance, defines the following insurance: Sharia insurance ( $T a$ 'min, Takaful, Tadhamun) is an effort to protect each other and help among a number of people / parties through investments in the form of assets and or tabarru' that provide a pattern of return to face certain risks through contracts (agreements) that are in accordance with sharia.

From the above definition, it appears that online insurance that applies the principle of sharia is mutually protecting and helps to help which is called "ta'awun", which is the principle of life to protect and help each other on the basis of ukhuwah Islamiyah among fellow members of sharia online insurance participants in the face of disaster (risk). Therefore, premiums on sharia online insurance are a number of funds paid by participants consisting of savings and tabarru' funds'. Savings funds are entrusted funds from participants of sharia online insurance and will receive an allocation of profit sharing (almudharabah) of net investment income earned each year. Savings funds along with the allocation of profit sharing will be returned to the participant if the relevant participant submits a claim, either in the form of cash value claims or insurance benefit claims. Whereas tabarru' is a donation or benevolent fund given and affirmed by insurance participants if at any time will be used to pay claims or insurance benefits (life or general insurance).

Islamic insurance has a different principle from conventional insurance institutions. These principles are: 1). Help and cooperate with one another; 2). Protect each other from various kinds of hardships and difficulties such as allowing money to thrive and not revolve in transactions that benefit the general public; 3 ). Responsible for each other; and 4). Avoiding the element of gharar (the element of uncertainty about the source of funds used to cover the claims and rights of policyholders), maysir (the gambling element that is described by the possibility of an injured party above the profits of other parties), usury (interest system). ${ }^{23}$

Islam emphasizes aspects of justice, like and like to face risks in every effort and investment that is initiated. This aspect offers the concept to replace gharar, maysir and usury which has been happening in conventional institutions. ${ }^{24}$ Sharia online insurance is different from conventional insurance not only at the level of packaging, but more deeply, at the level of operational concepts and principles.

23 Renny B. Supriyatni \& Asep Ahmad Fauji. Penerapan Prinsip Syariah Pada Lembaga Jasa Keuangan Perasuransian Di Indonesia. Jurnal Jurisprudence, Vol.7 No.1, 2017, 29-39, p. 33-34.

24 Renny B. Supriyatni \& Asep Ahmad Fauji. Penerapan Prinsip Syariah Pada Lembaga Jasa Keuangan Perasuransian Di Indonesia., p. 35. 
There are also others who have 9 principles which are operational characteristics of sharia insurance: 1). Sharia online insurance applies the concept of mutual responsibility and mutual responsibility. Takaful means mutual guarantee between group members; 2). A sharia insurance contract is not a sale and purchase contract where one party offers and the other party is willing to buy services at a certain price; 3). An Islamic insurance contract is an agreement of a group of people to guarantee or protect themselves against adversity or distress, agreed upon by type, through the collection of mutual funds; 4 ). In the event that one of the members suffers a loss due to misfortune or disaster, the member will receive an amount of money from a joint fund in accordance with the terms of the agreement. The loss is not a transfer of responsibility to another party or an intermediary, as practiced in conventional insurance; 5). In an Islamic insurance contract, the participants are both the insured and the guarantor. Each participant must pay a number of contributions into a joint fund called "takaful fund". The amount of contribution must be in accordance with the level of risk, which can be calculated using scientific and modern principles in the actuarial field; 6). To eliminate the element of gambling, each participant must be willing to set aside a donation fund (tabarru') in accordance with the risk costs. Thus, the compensation given to participants who experience misfortune / calamity comes from donated funds; 7). Sharia insurance participants are entitled to a surplus of funds (after payment of claims, reinsurance, technical reserves and fees), according to the agreed sharing system. Conversely, if there is a lack of funds, participants are also collectively responsible for closing it according to their respective proportions; 8). The role of insurance companies in Islamic insurance is as takaful fund managers for participants who are appointed through representative contracts (wakalah). As a fund manager, insurance companies get rewards in the form of fees, namely: management fees, performance fees (investment returns plus surplus underwriting); and 9). In the event of a deficit, for practical reasons, Islamic insurance companies are obliged to lend their capital to cover the shortfall, without interest. The loan will be covered by a future surplus. The amount of capital owned by the insurance company determines the underwriting capacity of takaful funds. ${ }^{25}$

The view of the Indonesian Ulama Council on sharia online insurance that needs to be known: ${ }^{26}$ First, online guarantee as a form of protection. In life, we

25 Teguh Suripto \& Abdullah Salam. Analisa Penerapan Prinsip Syariah dalam Asuransi. Jurnal Ekonomi Syariah Indonesia, Vol. 7 No.2, 2017, 128-137, p. 130-132.

26 Cermati. Fatwa MUI Tentang Asuransi, Apakah Haram atau Halal?. Retrieved From https://www. cermati.com/artikel/fatwa-mui-tentang-asuransi-apakah-haram-atau-halal Accesed $7^{\text {th }}$ August 2019. 
need a protection fund for bad things that will happen. This was confirmed by the MUI fatwa Number: 21/DSN-MUI/X/2001 states, in welcoming the future and efforts to anticipate the possibility of risks in economic life that will be faced, it is necessary to prepare a certain amount of funds early. One solution that can be done is to have online insurance managed by sharia principles. Insurance is needed to protect financial assets and lives whose risks cannot be predicted. Commonly insured things are houses, vehicles, health, education and lives. By having insurance, consumers do not need to worry about the risks that will befall because these risks can be minimized and receive compensation.

Secondly, online insurance as an element of help. All the religious teachings that exist must teach a helping attitude towards others. In social life, helping can be done in various forms, both financially and in kindness. MUI Fatwa Number: 21/DSN-MUI/X/2001 states that in sharia insurance there is an element of help among a number of people / parties through investment in the form of assets and/or tabarru' which provides a pattern of return to face certain risks through a contract (engagement) in accordance with sharia.

Third, online insurance as an element of goodness. In every sharia online insurance product contains an element of goodness or the term has a new tab. 'Literally, 'new tab' can be interpreted as kindness. The rule, the amount of premium funds collected is called a grant that will later be used for good, namely claims paid based on the contract agreed at the beginning of the agreement. The premium can be determined through existing references, for example refer to the mortality table to determine premiums on life insurance and morbidita tables to determine premiums on health insurance, with the condition not to include the element of usury in the calculation.

Fourth, share risks and benefits. In sharia-managed online insurance, risks and benefits are shared equally among the people involved in investment. This is considered quite fair and in accordance with religious law because according to the MUI, insurance should not be carried out in the context of seeking commercial benefits. The risk in question is the risk that occurs in one insurance participant affected by the disaster, then compensation (claims) obtained from other insurance participants. In other words, when a participant gets into trouble another participant also feels it. Likewise with the benefits. In Islamic insurance, the benefits obtained from the investment premiums in the mudharabah contract can be distributed to insurance participants and of course also set aside for investment companies.

Fifth, part of doing muamalah. Muamalah is a part of Islamic law that regulates human relations. Examples of relationships regulated in Islam are buying 
and selling and trading. It also becomes the foundation of sharia online insurance. According to the MUI online insurance is also part of doing muamalah because it involves humans in financial relationships. All rules and procedures must, of course, be in accordance with Islamic law. So in participating in doing muamalah, consumers are considered to participate in living religious orders.

Sixth, akad in sharia online insurance. MUI also confirmed the contractual rules used in insurance. The contract in question is an agreement between the insurance participant and the insurance company. In the contract there must not be elements of gharar (fraud), maysir (gambling), usury, zhulm (persecution), risywah (bribe), illicit goods and immoral because the purpose of the contract is mutual help by expecting pleasure and merit from Allah. There are 3 types of contracts in sharia online insurance that need to be known, namely: 1). Tijarah contracts are all forms of contract that are conducted for commercial purposes. The purpose of commercial goals in Islamic insurance is mudharabah, that is, investments made by insurance companies whose funds are obtained from insurance participants' premium funds. This is done in order to gain profit because in Islamic insurance, insurance companies are required to make investments; 2). Tabarru' contract 'is all forms of contract conducted with the purpose of virtue and help, not just for commercial purposes. The premium funds collected will be a grant fund managed by an insurance company. Furthermore, the collected grant funds are used for insurance claims for participants affected by the disaster; and 3). Wakalah contract is a contract in which the participant gives the power of attorney to the insurance company in exchange for giving a ujrah (fee). The nature of the contract is trustworthy, so the insurance company only acts as a representative (who manages the funds) so that the company does not bear the risk of investment losses. There is also no reduction in fees received by the company, except because of carelessness or default. ${ }^{27}$

The implementation of online insurance and conventional insurance is basically the same, but the difference lies in the convenience provided to consumers. Online insurance can be directly accessed anytime and anywhere through a computer or mobile phone connected to the internet.

27 Junaidi Abdullah. Akad-Akad Di Dalam Asuransi Syariah. Tawazun: Journal of Sharia Enonomic Law. Vol.1 No.1, 2018, 11-23, p.17-18 
Table 1. The Differences of Conventional Insurance and Islamic Online Insurance

\begin{tabular}{|c|c|c|}
\hline No. & Principle & Differences \\
\hline 1 & Concept & $\begin{array}{l}\text { Agreement between two or more parties, } \\
\text { whereby the Insurer binds himself to the } \\
\text { Insured, by accepting insurance premiums, to } \\
\text { provide replacement to the Insured. Whereas } \\
\text { in Islamic online insurance, a group of people } \\
\text { who help each other, guarantee each other, } \\
\text { and work together, by each issuing tabarru' } \\
\text { funds. }\end{array}$ \\
\hline 2 & Akad/ Contract & $\begin{array}{l}\text { Conventional Insurance uses a tabadulicontract, } \\
\text { a sale, and a purchase agreement. Of course, } \\
\text { in a sale and purchase agreement, there must } \\
\text { be clear sellers, buyers, goods (objects) that } \\
\text { are traded, prices, and sighat (ijab qabul or } \\
\text { handover). Whereasin Islamic online insurance, } \\
\text { the contract uswed is a takaful agreement (a } \\
\text { contract to help), which is a contract to help } \\
\text { fellow participants, ifone participant is affected } \\
\text { by a disaster, the other participants help with } \\
\text { Tabarru' funds (social funds). }\end{array}$ \\
\hline 3 & Funds Ownership & $\begin{array}{l}\text { The ownership of funds in Islamic online } \\
\text { insurance is a participant's right, the company is } \\
\text { only as a trustee to manage its sharia. Whereas } \\
\text { in conventional insurance, funds collected } \\
\text { from customers belong to the company, so the } \\
\text { company is free to determine the investment } \\
\text { allocation. }\end{array}$ \\
\hline 4 & The object & $\begin{array}{l}\text { In Islamic online insurance, limiting the } \\
\text { management of funds is only for objects } \\
\text { that are halal (clear) and may not contain } \\
\text { doubtful. But in conventional insurance } \\
\text { does not distinguish between halal or haram } \\
\text { objects, the most important object is to bring } \\
\text { benefits. }\end{array}$ \\
\hline
\end{tabular}




\begin{tabular}{|c|c|c|}
\hline 5 & Investment Funds & $\begin{array}{l}\text { In Islamic online insurance, if the premium } \\
\text { from the customer has not been used, then } \\
\text { the fund is invested in a sharia-based financial } \\
\text { institution and is based on a profit-sharing system. } \\
\text { As for conventional insurance management } \\
\text { of investments in the interest system that } \\
\text { contains elements of Maghrib. }\end{array}$ \\
\hline 6 & $\begin{array}{l}\text { Sharia Supervisory Board } \\
\text { (DPS) }\end{array}$ & $\begin{array}{l}\text { Nothing, so in many practices it contradicts } \\
\text { the rules of sharia. Whereas in Islamic online } \\
\text { insurance, has a DPS, which functions to oversee } \\
\text { the implementation of company operations } \\
\text { to be free from muamalah practices that are } \\
\text { contrary to Islamic principles. }\end{array}$ \\
\hline 7 & $\begin{array}{l}\text { Claim Payment } \\
\text { Source }\end{array}$ & $\begin{array}{l}\text { The source of claim costs is the company's } \\
\text { account, as a consequence of the guarantor } \\
\text { against the insured. Whereas in Islamic } \\
\text { online insurance, the source of claim costs } \\
\text { is obtained from the tabarru' account where } \\
\text { the participants bear one another. }\end{array}$ \\
\hline 8 & Guarantee / Risk & $\begin{array}{l}\text { Transfer of Risk, where there is a transfer of } \\
\text { risk from the Insured to the Insur, er. Whereas } \\
\text { in Islamic online insurance, sharing of Risk, } \\
\text { where there is a mutual responsibility between } \\
\text { one participant and another participant } \\
\text { (ta'awun) }\end{array}$ \\
\hline 9 & Profit & $\begin{array}{l}\text { Profits from Surplus Underwriting, reinsurance } \\
\text { commissions, and investment returns are } \\
\text { profits of the company. Whereas in Islamic } \\
\text { online insurance, the profits obtained are not } \\
\text { entirely the property of the company but are } \\
\text { shared with the participants. }\end{array}$ \\
\hline
\end{tabular}

Source: Analysed from the primary source

In principle, how to design sharia online insurance products is not too much different from, how to design conventional products. Nevertheless, the 
differences between the two can determine the halal-haram of a product, for example when determining the contribution of premiums, premium reserves, in conventional insurance based on interest calculations (technically), while online sharia insurance is based on the Profit Sharing Concept; and also the difference in determining insurance costs, for online sharia insurance is not charged to participant funds, but taken from the company. ${ }^{28}$

Related to the implementation of financial institutions, especially online insurance in Indonesia, every customer has the right to legal certainty in guaranteeing the protection of his rights as mentioned in Article 1 paragraph 1 of Law Number 8 of 1999 concerning Consumer Protection, namely "Consumer protection is all efforts that guarantee there is legal certainty to provide protection to customers". The intended protection includes general protection and special protection. General protection is material protection in the form of the safety of customer funds, transparency of information, advocacy, etc. whereas special protection is the spiritual protection of customers. ${ }^{29}$ The spiritual protection in question is one of the important components in the economic life of the Islamic religion, namely muamalah.

Speaking of spiritual protection, it can be said that all online insurance customers have spiritual rights that need to be protected. Spiritual rights are religious rights that are owned by every human being. Especially in Indonesia, spiritual rights are more identical to the rights of Muslims, because the majority of Indonesia's population is Muslim. Consumer protection perspective, Ro'fah Setyowati said that consumers of Islamic financial institutions have spiritual or religious rights, in Indonesia those rights are guaranteed or protected through the form of sharia principles in the implementation of sharia-based online insurance. ${ }^{30}$ This thinking arises from the spiritual aspects inherent in each person, especially in the consumer. ${ }^{31}$

28 Herry Ramadhani. Prospek dan Tantangan Perkembangan Asuransi Syariah di Indonesia. Al-Tijary, Vol.1 No.1, 2015, 57-66, p.60-61.

29 Ro'fah Setyowati. Consumers Spiritual Rigths In The Islamic Bangking Dispute Out Of Court Settlement In Indonesia. Journal Of Social Studies Education Research, Vol.9 No.4, 2018, 334-351, p. 334.

30 Ro'fah Setyowati, Consumers Spiritual Rigths In The Islamic Bangking Dispute Out Of Court Settlement In Indonesia, p. 335.

31 Setyowati, Ro'fah, Abubakar, Lastuti \& Rodliah, Nunung. Sharia Governance on Islamic Banking: Spiritual Rights Perspective on Consumer Protection in Indonesia. Diponegoro Law Review, Vol. 2 No.1, 2017, 227-244, p. 227-228. 
The need to live a good economic life based on sharia principles needs to be supported and paid attention to by the government, society or community associations. Implementation of this support can be through regulations, and an active role related to the spiritual rights of the community. As mentioned above from the perspective of consumer protection, the application of sharia principles in Islamic financial institutions is a form of guaranteeing the protection of spiritual rights. The spiritual nature itself has been explained in the principles of consumer protection in the Consumer Protection Act. Also, compliance with Islamic principles in Islamic financial institutions has also been regulated in various laws and regulations related to their respective fields. ${ }^{32}$

The terms of the contract that have been explained above are one form of clear regulation relating to guaranteeing the protection of spiritual rights from the application of online insurance governance that applies sharia principles. Provisions regarding the use of agreements based on the DSN-MUI Fatwa constitute the fulfillment of sharia principles in the organization of online insurance. Attention to the protection of spiritual rights is needed to build an Islamic-based economic system, especially client insurance that is currently developing.

\section{Conclusion}

The existence of insurance in Indonesia has experienced rapid growth and development, this is due to the existence of information technology. Many insurance companies in the implementation of insurance relies on technology. Such insurance is often called online insurance. Online insurance in Indonesia provides many conveniences and advantages compared to insurance in general. In Indonesia, the definition of insurance stated in Law Number 40 of 2014 concerning Insurance states that Insurance is an agreement between two parties, namely an insurance company and a policy holder, which is the basis for receiving premiums by insurance companies in return for: a). Providing compensation to the insured or policyholder due to loss, damage, costs incurred, loss of profit, or legal liability to third parties that may be suffered by the insured or policyholder due to an uncertain event; or b). provide payments based on the death of the insured or payments based on the life of the insured

32 Setyowati, Ro'fah, Abubakar, Lastuti \& Rodliah, Nunung., Sharia Governance on Islamic Banking: Spiritual Rights Perspective on Consumer Protection in Indonesia, p. 231. 
with benefits the amount of which has been determined and / or based on the results of fund management.

In Islam, insurance is basically permissible as long as it applies principles that are not contrary to Islam. Like online insurance, which implements Islamic law must contain principles that strongly support the existence of a sense of calm, security, mutual help, fair, and even mutual benefit between fellow policyholders and companies. So that online insurance companies can run their business based on Islamic sharia, in each online insurance company is always supervised by the Sharia Supervisory Board. In Indonesia, which establishes the Sharia Supervisory Board is the National Sharia-Indonesian Ulama Council (DSN-MUI). The DSN-MUI in its fatwa on general guidelines for sharia insurance, defines the insurance as follows: Sharia insurance ( Ta' $\mathrm{min}$, Takaful, Tadhamun) is an effort to protect each other and help among a number of people / parties through investment in the form of assets and or tabarru' which provide a pattern of return to face certain risks through a contract (agreement) in accordance with sharia. The problem is, at this time there are still quite a lot of Muslim communities who do not understand the importance of insurance based on Islamic sharia. The terms of the contract that have been explained above are one form of clear regulation relating to guaranteeing the protection of spiritual rights from the application of online insurance governance that applies sharia principles. Provisions regarding the use of agreements based on the DSN-MUI Fatwa constitute the fulfillment of sharia principles in the organization of online insurance.

\section{References}

\section{Book}

Suteki \& Galang Taufani, Metodologi Penelitian Hukum (Filsafat, Teori Dan Praktik), Depok: PT RajaGrafindo Persada, 2018.

Zainuddin Ali, Metode Penelitian Hukum, Jakarta: Sinar Grafika, 2018.

Article

Ahmad Ajib Ridlwan. Asuransi Perspektif Hukum Islam. ADZKIYA: Jurnal Hukum dan Ekonomi Syariah, Vol.4 No.1, 75-88: 2016.

Dedi Kusdani. Persepsi terhadap sikap dan minat pengguna layanan internet pada perusahaan jasa asuransi. Jurnal organisasi dan manajemen, Vol.10 No.2, 97-112: 2014. 
Deny Guntara. Asuransi Dan Ketentuan-Ketentuan HUkum Yang Mengaturnya. Jurnal Justisi Ilmu Hukum. Vol.1 No.1, 29-44: 2016.

Hal R. Varian. Redistributive taxation as social insurance. Journal of public Economics. Vol.14 No.1, 49-68: 1980.

Hari Sutra Disemadi \& Kholis Roisah. Kontrak Build Operate Transfer Sebagai Sarana Mewujudkan Kesejahteraan Rakyat. Jurnal Komunikasi Hukum (JKH), Vol.5 No.2, 126-138: 2019.

Hendrisman Rahim. Optimisme pertumbuhan asuransi indonesia; proyeksi perkembangan lima tahun (2014-2018). Jurnal Asuransi dan Manajemen Risiko, Vol.1 No.2, 1-21: 2013.

Hari Sutra Disemadi, \& Paramita Prananingtyas. Perlindungan Hukum Terhadap Nasabah Perbankan Pengguna CRM (Cash Recycling Machine). Jurnal Magister Hukum Udayana (Udayana Master Law Journal), Vol.8 No.3, 286-402: 2019.

Herry Ramadhani. Prospek dan Tantangan Perkembangan Asuransi Syariah di Indonesia. Al-Tijary, Vol.1 No.1, 57-66: 2015.

Hari Sutra Disemadi. Risk Management in the Provision of People's Business Credit as Implementation of Prudential Principles. Diponegoro Law Review, Vol.4 No.2, 194-208: 2019.

Junaidi Abdullah. Akad-Akad Di Dalam Asuransi Syariah. Tawazun: Journal of Sharia Enonomic Law. Vol.1 No.1, 11-23: 2018.

Lambang Andri Prabawa \& Mohammad Rizan. Perkembangan Teknologi Informasi Dan Komunikasi, Inovasi, Kepemimpinan Dan Kinerja Perusahaan: Studi Transformasi PT. POS Indonesia. Jurnal Pendidikan Ekonomi dan Bisnis, Vol.3 No.1, 81-99: 2015.

Novi Puspitasari. Sejarah dan Perkembangan Asuransi Islam serta Perbedaannya dengan Asuransi Konvensional. Jurnal Ekonomi Akuntansi dan Manajemen, Vol.10 No.2, 35-47: 2011.

Ramin Cooper Maysami \& John Joseph Williams. Evidence on the relationship between Takaful insurance and fundamental perception of Islamic principles. Applied Financial Economics Letters, Vol.2 No.4, 229-232: 2006. 
Renny B. Supriyatni \& Asep Ahmad Fauji. Penerapan Prinsip Syariah Pada Lembaga Jasa Keuangan Perasuransian Di Indonesia. Jurnal Jurisprudence, Vol.7 No.1, 29-39: 2017.

Setyowati, Ro'fah, Abubakar, Lastuti \& Rodliah, Nunung. Sharia Governance on Islamic Banking: Spiritual Rights Perspective on Consumer Protection in Indonesia. Diponegoro Law Review, Vol. 2 No.1, 227-244: 2017.

Ro'fah Setyowati. Consumers Spiritual Rigths In The Islamic Bangking Dispute Out Of Court Settlement In Indonesia. Journal of Social Studies Education Research, Vol.9 No.4, 334-351: 2018.

Robert E. Keeton. Insurance law rights at variance with policy provisions. Harvard Law Review, Vol.83 No.5, 961-985: 1970.

Teguh Suripto \& Abdullah Salam. Analisa Penerapan Prinsip Syariah dalam Asuransi. Jurnal Ekonomi Syariah Indonesia, Vol. 7 No.2, 128-137: 2017.

Uswatun Hasanah. Asuransi dalam Perspektif Hukum Islam. Asy-Syir'ab: Jurnal Ilmu Syaria'ah dan Hukum, Vol.47 No.1, 239-267: 2013

Wiwik Andriani. Pengaruh Kapasitas Sumber Daya Manusia dan Pemanfaatan Teknologi Informasi Terhadap Keterandalan dan Ketepatwaktuan Laporan Keuangan Pemerintah Daerah (Studi pada Pemerintah Daerah Kab. Pesisir Selatan). Jurnal Akuntansi \& Manajemen, Vol.5 No.1, 6980: 2010 .

\section{Website:}

Budi Setyawan. Asuransi Dilihat Dari Perspektif Hukum Islam (Syariab). Retrieved From https://rangselbudi.wordpress.com/2011/10/26/ asuransi-dilihat-dari-perspektif-hukum-islam-syariah/ Accesed $7^{\text {th }}$ August 2019.

Cermati. Fatwa MUI Tentang Asuransi, Apakah Haram atau Halal?. Retrieved From https://www.cermati.com/artikel/fatwa-mui-tentang-asuransiapakah-haram-atau-halal Accesed $7^{\text {th }}$ August 2019.

Duwitmu. 10 Situs Beli Asuransi Online Terbaik Terpercaya 2019 (Diawasi OJK). Retrieved From https://duwitmu.com/asuransi/beli-asuransi-online- 
terbaik-2019/ Accesed 6 ${ }^{\text {th }}$ August 2019.

Wong Sadli, Haram Halalkah Asuransi Itu?, Retrieved From https://www. kompasiana.com/sang_walisongo/5c7e0aad677ffb416f0d7a48/haramhalalkah-asuransi-itu?page $=$ all Accesed 21 th November 2019. 